\title{
Sistema notarial brasileiro x norte-americano - comparação pelas diferenças
}

\author{
Notaries north american system $x$ notaries \\ brazilian system - comparison through the differences
}

Maria Maria Martins Silva Stancati ${ }^{1}$

\section{RESUMO}

Este artigo pretende explorar a temática da função do Notário na comparação entre o Sistema de Notariado Norte-Americano e o Sistema de Notariado Brasileiro. Eles surgem, no contexto histórico da mesma forma, mas num dado momento se separam quando passa a aparecer os sistemas jurídicos diferentes de acordo com cada cultura, assim, surgem o Civil Law com base em provas documental e o Common Law com base no testemunho oral. Dessa diferença entre documento e testemunho que se desenvolve as atribuições da função notarial.

\section{PALAVRAS-CHAVE}

Função notarial; comparação pelas diferenças; cultura jurídica.

\section{ABSTRACT}

This article will explore the theme of the notary's role in the comparison of the Notaries North American System and the System of Notaries Brazilian. They arise in the historical context in the same way, but at some point they separate when it starts to show the different legal systems in accordance with each culture, thus arise the Civil Law based on documentary evidence and the Common Law based on oral testimony. This difference between document and testimony that develops the powers of the notarial function.

\section{KEYWORDS}

Notarial function; comparison through the differences; legal culture.

\section{INTRODUÇÃO}

Este artigo pretende apresentar o tema notariado na comparação entre o Sistema Brasileiro e o Norte-Americano. Inicia-se com o histórico do direito notarial e registral,

1 Doutoranda em Direito pelo PPGD-UNESA/RJ; Mestre em Direito pelo PPGD-UNESAIRJ; Professora de Direito Civil - UNESA/RJ; ex-delegatária da Serventia de Protesto de Títulos de Eugenópolis - MG. 
pois a função Notas e Registro estão intimamente ligadas principalmente no notariado latino que é a grande base histórica a ser apresentada. Por isso, apesar do artigo elucidar o tema notarial, o tema registro será citado em alguns momentos.

Compreendido o surgimento da função notário é apresentado os dois grandes sistemas notariais hoje existentes: o Sistema Notarial Anglo-saxão, típico de países de Common Law surgido na Inglaterra e o Sistema Notarial Latino de influência inicialmente Romana construído na França, Itália, Espanha e Portugal típico dos países de Civil Law. Todavia, no artigo, percebe-se que os sistemas não são uma regra a ser seguida visto que alguns estados dos Estados Unidos estão adotando um notário muito próximo ao notário latino.

No Sistema Notarial Norte-Americano serão exploradas as figuras do Civil Law Notaries e do Notary Public indicando suas atribuições, responsabilidades e forma de ingresso na função. O mesmo é feito com o notário brasileiro que se apresenta comportando as funções das duas figuras americanas. Dele também são extraídos as atribuições, responsabilidade e forma de ingresso na função.

$\mathrm{O}$ artigo conclui com o apontamento das diferenças dos Sistemas e a indicação, da necessidade de se aprimorar cada sistema mantendo suas características originais para não perder a identidade. Evoluir pelo aprimoramento pode levar a agregar características de outros sistemas que não significa perder a identidade, mas dar um passo rumo ao sucesso de cada sistema em cada cultura.

\section{HISTÓRIA DO DIREITO NOTARIAL E REGISTRAL}

Há uma crença que o Direito Notarial e Registral é um direito novo, moderno e que nasceram juntos, como se fossem irmãos gêmeos. Contudo a verdade se encontra há anos de distância. Primeiro nasceu a função Notarial ou Notas, cujo exercente era chamado de Tabelião ou Notário. A partir da evolução das sociedades e da necessidade de se ter uma prova da propriedade da terra e um cadastro desta pelo Estado emergiu a função registro exercida pelo registrador. Eis a primeira e principal diferença entre as funções: notário formaliza juridicamente a vontade das partes num documento e registrador registra no livro próprio o direito do indivíduo.

Os notários ou tabeliães surgiram quando a escrita se tornou importante para a elaboração de documentos. Havia documentos corriqueiros e havia documentos que necessitavam ser perpetuados, pois descreviam fatos importantes. Estes últimos eram confeccionados por um cidadão com perícia redatora e conhecimento a fim de certificar a validade e veracidade do mesmo. E, como poucas pessoas detinham a arte da escrita com perícia, esses cidadãos logo se destacaram pela sua importância no contexto social.

Inicia-se a referência à esta função no antigo Império Egípcio com o escriba, antecessor do notário. Como era um indivíduo que detinha o conhecimento da linguagem, ele desfrutava de importância social. Associado à divindade, detinha os poderes do raciocínio, da pluma, da tinta e da caligrafia. Também era grande conhecedor dos textos antigos, bem como dos hieróglifos, da cosmografia, geografia e rituais cerimoniais. Seus documentos possuíam fé perante sua comunidade.

O escriba era como um funcionário público, servindo à administração, pois este também documentava a prática administrativa. Auxiliava o faraó, o diretor do tesouro e as tropas do exército, através de uma estrutura hierarquizada de diretores e vice-diretores de escribas. Além de sua atuação estatal, ele atuava de forma paraestatal, auxiliando os 
indivíduos na documentação dos fatos da vida em sociedade. Os escribas confeccionavam seus documentos iniciando com a data e terminando com sua assinatura e das testemunhas, que podiam ser não somente do ato, mas também do fato.

A função de escriba não se estagnou no Egito, mas foi exportada para outras comunidades sempre se adaptando ao contexto e necessidade local sem perder sua essência. Foi utilizada na Índia, Babilônia, e pelo povo hebreu, que dividiu entre o escriba do rei, funcionário com atividades variadas incluindo a interpretação das leis e uma função quase sacerdotal; e escriba do povo que redigia os acordos privados de compra e venda, arrendamento, convenções patrimoniais do casamento.

Em Roma é que a função começa a tomar os contornos da realidade que hoje conhecemos. Neste momento, havia vários indivíduos com funções bem definidas para $o$ auxílio da vida em comunidade, mas dois chamam a atenção neste estudo: o notarii, que tomava notas dos fatos a serem documentados e os tabeliones, que redigiam os documentos.

Nas compilações justinianas, os Tabeliães deveriam exercer suas atividades num local denominado praça. Cada Tabelião tinha sua praça, não podendo agir além da praça designada. Essa estrutura lembra a competência tal como hoje conhecemos. E, para exercer esta digna função, o indivíduo deveria possuir profundo conhecimento da escrita, do Direito, aptidão física e psíquica, ser mestre no raciocinar e ser aprovado em exame realizado pelos seus pares.

Atravessando os séculos e culturas, aterrisso na Itália do século XIII, precisamente na Universidade de Bolonha, sendo considerado um marco para o Direito Notarial Moderno e inaugurando do chamado Direito Notarial Latino, que mais tarde será absorvido pelo Sistema Notarial Latino. Na chamada Escola de Bolonha houve o cuidado de tentar organizar e aprimorar o sistema já existente na Itália, criando parâmetros e estrutura doutrinária para que servissem de exemplo aos demais países europeus.

Um dos grandes avanços foi o estudo exegético da legislação onde dividiram o ato notarial em três partes: o prólogo constando a capacidade mental das partes contratantes, o objeto sendo este o objeto da contratação e seu poder de disposição e as testemunhas do ato que seriam no mínimo três e no máximo quinze ${ }^{2}$. Além de Bolonha, Espanha (Aragon e Valência) e Portugal também tiveram a preocupação acadêmica e institucional no aperfeiçoamento desta atividade, elevando, o Direito Notarial a status de cientificidade criando a verdadeira ciência do estudo com curso próprio nas Universidades.

No Brasil, a função notarial e de registro, com ênfase no registro de imóveis, nasceu junto com seu descobrimento, em 1500. Ao serem descobertas, as Terras Tupiniquins, já possuíam matrícula pelo Tratado de Tordesilhas que dividiu as terras do além-mar entre Portugal e Espanha. E, posteriormente, a divisão do Brasil nas sesmarias constantes no Livro Tombo em Portugal ${ }^{3}$. Quanto à legislação, num primeiro momento, herdou-se, dos patrícios, as Ordenações Filipinas, Manuelinas e Afonsinas, bem como a lei sesmarial portuguesa.

$\mathrm{Na}$ Terra de Vera Cruz, sim, pode-se falar que as funções notariais e registrais nasceram juntas. Elas poderiam ser exercidas por pessoas distintas ou não, mas já havia a diferença entre o notário, que descrevia a vontade das partes e o registrador (talvez não com este nome específico) que registrava em seu livro a vontade da parte descrita pelo

\footnotetext{
2 Essa estrutura pode ser verificada no CC/02 em seu artigo 104, c/c 215.
}

${ }^{3}$ Este livro era assim chamado porque arquivava-o na Torre do Tombo. 
notário. Inicialmente, a vontade de transmitir a terra era formalizada pelos capitães das capitanias hereditárias que repassavam a informação quanto ao domínio da terra para o Rei de Portugal, que arquivava essas informações. Quanto aos casamentos, nascimento e óbitos, estes ficavam a cargo do padre presente no local do acontecido.

Posteriormente, com a edição da Lei de Terras, Lei 601 de 1850, a função de notário e registrador foi atribuída ao Vigário das paróquias. Daí vem a expressão registro do vigário. Como cada local era dividido em freguesias e cada uma destas havia um vigário, o Império decidiu que este detinha os atributos para cumprir as funções notariais e registrais, como já vista, de grande importância. Esta opção também se deu pela religião católica ser a oficial, na época, e porque o vigário tinha muita proximidade com a população posto que estivessem espalhados por todo o território.

Os vigários eram responsáveis por colher a declaração das partes e transcrevê-las por escrito, ou quando estes já entregavam por escrito, era responsável por conferi-las. Ele datava a apresentação da declaração e registrava em livro próprio constante no acervo paroquial. Quando se tratava de registro de terras, este livro era enviado ao diretor geral das terras públicas para formar o registro geral das terras. Por isso que é tão comum encontrar pessoas idosas com propriedade ou terras recebidas por herança que não se encontram no acervo da serventia extrajudicial, mas somente nos acervos paroquiais.

\section{SISTEMA NOTARIAL}

O sistema notarial organiza-se com base no sistema jurídico adotado. Hoje dois grandes sistemas são encontrados: o Common Law e o Civil Law.

\section{Sistema Notarial Anglo-saxão}

Esse sistema é típico de países que adotam a Common Law, ou seja, não possuem uma compilação de leis num único código; ao invés, possuem leis esparsas, decisões jurisprudenciais, costumes, prova oral com grande valor e outras formas de explorar o direito para emitir uma decisão. A base desse sistema está no princípio da oralidade e o testemunho como prova maior. Os documentos podem ter o mesmo, menor ou igual valor probatório que a palavra do indivíduo.

Adotado pelo Império Britânico e expandido para as colônias de cultura inglesa, o Sistema Notarial Anglo-saxão conta com a presença do Notary Public, que apenas auxilia a parte em alguns atos da vida na formalização da vontade, sem prestar assistência jurídica, e não precisando da formação jurídica nem de concurso público para exercer o cargo de função privada.

De nada adianta o indivíduo ter um documento dizendo acerca de seu direito, se, como explica Hart em seu livro $O$ Conceito de Direito, o direito é o que o Tribunal diz que ele é, em se tratando do direito presente nos países de Common Law. O fato da base desse sistema ser o princípio da oralidade e a jurisprudência dos tribunais incompatibiliza o direito traduzido num documento, que muitas vezes poderá ser contraditório com o relato oral do indivíduo ou testemunhal. Há sim construções legislativas a serem seguidas, como no sistema de Civil Law e documentos atestando fatos, mas essas não são tão estanques. Há sempre uma margem para o juiz transformar o direito.

O sistema de Common Law gera mais liberdade para as partes chegarem a um acordo sem a necessidade do uso da lei em si, especialmente no sistema americano onde 
temos a força da palavra pesa. Explico: as partes acordam pela venda de um imóvel. A prova da propriedade está na palavra de quem vende dizendo ser o real proprietário e na boa fé de quem quer comprar. Não há necessidade de certidão emitida por nenhum órgão atestando a propriedade.

Parece bem prático e livre de burocracia, porém esta conduta traz inúmeras implicações à economia no todo. O exemplo mais recente é a crise das hipotecas podres americana. A falta de um registro dito burocrático, como o brasileiro, se tornou o principal fator para a crise financeira americana, pois os registros dos imóveis são feitos por agências que recolhem as declarações preenchidas pela internet e não verificam os dados.

A prova de este sistema ser falho está na compra do Empire State pelo Jornal New York Daily com nome falso de Nelots Properties, tendo como testemunha a atriz que interpretou a loira do filme King Kong, Fay Wray, e como notário o ladrão de bancos Willie Sutton. A transação imobiliária demorou cerca de noventa minutos. Além da compra do imóvel, houve uma hipoteca dando este em garantia. Enquanto no Brasil já se fala em $e$-folium ${ }^{4}$, nos EUA ainda se fala em implantar um Registro Geral de Imóveis.

\section{Law}

\section{Sistema Notarial Latino/ Romano-Germânico/ Continental/de Civil}

Esse sistema, adotado pelo Brasil e pelos países integrantes na União Internacional do Notariado Latino ${ }^{5}$, tem como características as funções já vista no histórico do notariado de forma aprimorada. O titular da função possui natureza híbrida, pois exerce funções públicas e privadas, conferindo fé pública aos documentos por estes emanados e atuando como profissional liberal quando aconselha as partes sobre um determinado ato notarial e registral sempre de forma individualizada e imparcial.

Apesar de exercerem função pública, estes não se enquadram como funcionários do estado, nem por ele é remunerado. Ao exercer sua atividade, o faz em caráter privado, devendo a delegação do serviço ser personalíssima depois da aprovação em concurso público de provas e títulos. A serventia ${ }^{6}$ é um braço do estado. Nela são exercidas funções de interesse do Estado porque assim ele o quis e desta forma escolheu. Hoje, os titulares são pessoas privadas. Até 1988, antes da nova constituição, o serviço era exercido por particulares, quando recebido por herança, ou por servidores públicos dos quadros do Tribunal de Justiça.

Este sistema tem uma boa conversa com a tradição do Civil Law visto que há uma compilação de leis que são obedecidas em detrimento dos costumes e precedentes judiciais. A prova de grande valor é a documental. Sempre. Por mais que a testemunha seja boa, que a outra parte esteja de boa-fé, "quem primeiro registrou é o dono"7. Por isto que uma das características do serviço é a possibilidade de fixar a data e hora no

\footnotetext{
${ }^{4}$ É o Registro de Imóveis eletrônico. Hoje cada comarca possui suas serventias que são divididas em ofícios pelas suas atribuições de serviços. Cada ofício, dentre seu serviço, (ex.: RGI) possui sua competência, (registro dos imóveis do bairro $\mathrm{x}$ ). Para cada comarca há um distribuidor e nele pode ser requerida a certidão se $\mathrm{o}$ indivíduo ingressou com um título a registrar sua propriedade, ou em cada ofício pode ser requerida a certidão se Fulano possui um imóvel. Com o e-folium, esse banco de dados será de âmbito nacional. Não importa o ofício de qual Estado do Brasil 0 indivíduo requerer a certidão, ela trará informações de todos os Ofícios de Imóveis do Brasil.

5 http://www.uinl.org/1/home-page

${ }^{6}$ De acordo com a atual nomenclatura não se fala mais em cartório, mas em Serventia Extrajudicial, Serventia apenas ou Ofício seguido de seu número conforme estipulado pelo Estado. Ex.: $1^{\circ}$ Ofício do Registro de Imóveis da Comarca de XXX.

${ }^{7}$ Expressão corriqueira no Direito Brasileiro: só quem registra é o dono.
} 
documento, para assegurar em discussões posteriores, quem primeiro emitiu a declaração de vontade. Explico: João, às $11 \mathrm{~h}$ vendeu um terreno para José através de uma escritura pública. Às 14h, João vendeu este mesmo terreno para Thiago. Quando José e Thiago ingressarem com a escritura de compra e venda visando o registro no RGI, José terá prioridade no registro tendo em vista que seu negócio realizado primeiro ${ }^{8}$.

Assim, pelo sistema do notariado latino, o indivíduo se apresenta na serventia visando formalizar juridicamente sua vontade. O titular desta serventia, também chamado de notário ou tabelião, recolhe a vontade da parte, de forma oral ou através de minuta, aconselha sobre a melhor forma de conseguir o efeito prático escolhendo o melhor ato ${ }^{9}$, redige o documento, le em voz alta, corrige os erros, assina e depois colhe a assinatura das partes e das testemunhas do ato. Mantém o original deste documento em seu arquivo e emite uma certidão ou o translado do documento para a parte que terá o mesmo valor do original. Qualquer interessado pode pedir certidão do ato para verificar se este efetivamente ocorreu ${ }^{10}$.

\section{SISTEMA NOTARIAL NORTE-AMERICANO}

O Sistema de Notariado Americano, baseado no Sistema Anglo-saxão, é composto por dois atores sociais chamadas de Civil Law Notaries ou Latin Notaries e o Notary Public. São figuras com atribuições diversas que não se confundem nem interferem uma na outra, podendo o trabalho de uma complementar a da outra trazendo melhor segurança ao ato.

\section{Civil Law Notaries/Latin Notaries}

Esta função, que lembra o tabelliones romano, típico dos países de Civil Law é exercida por advogados, estabelecidos em associação de advogados ou unitariamente (private pratice), atuando na área do direito privado, não contencioso, ou seja, não levam essas questões ao Tribunal (Court), exercendo na sua função de rascunhar, redigir e arquivar a versão final de instrumentos jurídicos para as entidades privadas ou pessoas físicas, prestando-lhe, também, o aconselhamento jurídico.

Os Civil Law Notaries estão impedidos de exercer, simultaneamente, a função de advogado e notário. Caso o instrumento que emitiram seja impugnado no Tribunal, estes não podem advogar em favor da parte. E, nada impede, quando seja um contrato que

\footnotetext{
8 Lei 6.015/1973 - Art. 192. Prevalecerão, para efeito de prioridade de registro, quando apresentados no mesmo dia, os títulos prenotados no protocolo sob número de ordem mais baixo, protelando-se o registro dos apresentados posteriormente, pelo prazo correspondente a, pelo menos, um expediente diário.

Parágrafo único. Excetuam-se da norma deste artigo as escrituras públicas lavradas na mesma data que, apresentadas no mesmo dia, determinem taxativamente a hora da sua lavratura, prevalecendo, para efeito de prioridade, a que foi lavrada em primeiro lugar.

9 Verifica se no caso em concreto, por exemplo, é melhor uma Ata Notarial ou uma Escritura Pública.

10 Lembro-me de um fato curioso que foi relatado por um funcionário de um RGI (conto o milagre, mas não o nome do santo!). Uma senhora foi ao dito RGI exigindo o funcionário não dessas informações sobre seu imóvel a ninguém, pois ela descobriu que seu vizinho tinha conhecimento que o imóvel estava no nome dela. O funcionário explicou que pelo princípio da publicidade qualquer pessoa poderia pedir informações sobre qualquer imóvel que estivesse registrado naquela Serventia e que ele não poderia negar tal informação, pois estaria descumprindo um dever funcional. A Senhora saiu chateada e até hoje não fala mais com o funcionário.
} 
envolve alta transação comercial, este seja assinado pelo Civil Law Notary e pelo advogado da parte (attorney).

Eles são investidos na função pública com o poder de autenticidade dos documentos. Não são funcionários públicos nem recebem remuneração pelo estado, como o notariado brasileiro, são pagos pelos serviços realizados através de taxa. Para exercer a função eles devem possuir alto grau de especializaçao, exigindo, em alguns Estados o nível de mestrado em direito com especialização em direito notarial. Algumas universidades oferecem a graduação em direito notarial e não somente a especialização.

A área de atuação do Civil Law Notaries é o direito privado apenas em relação aos indivíduos (não englobando fatos que o Estado é chamado ${ }^{11}$ ), em rel ao direito de família, testamentos, sucessões, direito de propriedade como a compra e venda e hipotecas, aquisição e transaferência de propriedade comercial, direito societário e formação de empresas, elaboração de contratos, planejamento imobiliário, procurações, dentre outros. Sua função se restringe a elaborar, autenticar as cópias dos originais que este realizou, registrar e arquivar os instrumentos transacionais. Ele é um repositório público de documentos.

Assim, as partes comparecem perante um Civil Law Notary para realizar um contrato. Podem levar consigo um advogado que participará da discussão. Após concluído os ajustes, é redigida a minuta do contrato e revisada ${ }^{12}$. Elaborado o documento, deste é extaída uma cópia e entregue as partes com presunção de autenticidade, validade e eficácia administrativa e juridicamente. Dependendo do tipo de acordo não há necessidade de autenticação pelo Notary Public, salvo quando há transferência de bens imóveis.

As características deste instrumentos são a presunção de validade e regularidade, autenticação do ato, valor probatório, é auto-executável e fixa a data da confecção do documento bem como da realização do negócio previsto neste. Este, também, constitui prova plena do acordado valendo, inclusive, contra os sucessores das partes. Outro dado interessante é que estes instrumentos são documentos oficiais, mas não necessariamente públicos. Se confeccionados na forma pública, deles podem se extrair certidão; se confeccionados na forma privada, o original é entregue diretamente a parte.

Para iniciar a atuação neste serviço, o advogado, além da especialização exigida começa como trainee em algum escritório de Civil Law Notaries. Após alguns anos é elevado a junior associate para posteriormente ter sua própria firma ou trabalhar de forma autônoma. A prática da atividade sofre regulamentação sendo o número de notários restrito e em alguns lugares há distribuição da competência através dos distritos notariais. Quando vaga uma posição, os advogados interessados devem-se candidatar para terem seus currículos avaliados e prestarão o exame especial de Civil Law Notary ocorrida no estado no qual pretendem atuar. Há, também, o caso de vagas herdadas.

A Associação Nacional de Civil Law Notareis (NACLN) elaborou um estatuto (Model Civil Law Notary Act) ${ }^{13}$ para uniformizar a função traçando os serviços a serem cumpridos, os requisitos do exercente e objetivos a serem almejados. Interessante quanto ao princípio da publicidade dos atos. De acordo com o estatuto elaborado, as certidões dos atos, que tem a mesma força do original, serão fornecidas apenas a quem o Civil Law

11 Exemplificando, no direito brasileiro, o caso de responsabilidade objetiva do Estado.

12 Não posso afirmar se no ato as partes, testemunhas (se há!) e Civil Law Notary assinam o instrumento. Até onde pesquisei essa informação não foi precisa.

13 NATIONAL ASSOCIATION OF CIVIL LAW NOTARIES. Model Civil Law Notary Act. Disponível em: $<$ http://nacln.org/files-pdf/Model\%20NACLN\%20Act.PDF>. 
Notary entender que tem legítimo interesse no conteúdo do ato. Logo presume-se que ele pode recusar a certidão.

Alabana, Florida, Louisina e Puerto Rico são os estados americanos que adotam o sistema de Civil Law Notaries, sendo que os dois primeiros já adotaram o Model Civil Law Notary Act, apesar do sistema jurisdicional americano ser da Common Law. Próximo aos EUA, Quebec, inversamente do resto do Canadá também adotou este sistema de notariado. Uma proposta interessante do Model Act é a absorção das funções do Notary Public pelo Civil Law Notary tornando-se, cada vez mais próximo, ao Sistema do Notariado Latino existente nos países da América Central e do Sul, Europa Continental (França, Espanha, Itália e outros), África de língua francesa, Xangai e outros.

\section{Notary Public}

É um funcionário nomeado pelo governo estadual, com investidura por tempo determinado (geralmente de quatro a sete anos) cuja função é servir ao público em geral como uma testemunha imparcial dos documentos importantes que são assinados em sua presença. Seus poderes e qualificações são diversos do Civil Law Notary e mais limitados. Eles não necessitam ter formação jurídica, não podem preparar os documentos e instrumentos nem auxiliar com conselhos legais as partes. A fé pública de seus atos se restringe a autenticação da assinatura e da data.

Em alguns Estados há a necessidade de aprovação em exames e específicos e frequência em cursos, mas na maioria deles, basta preencher um formulário e pagar uma taxa. Quanto ao local de atuação, no geral, estes são ilimitados com relação a competência geográfica, podendo praticar seus atos em qualquer lugar dos EUA. Todavia, alguns estados possuem um acordo com os estados limítrofes que permite a possibilidade do notário do estado conveniado possa exercer sua função neste território. Outros Estados impedem que notários de lugares diversos exerçam, ali, suas funções. A remuneração do notário se dá pela taxa do serviço.

O Notary Public, ao contrário do Civil Law Notary é encontrado em todos os Estados do EUA e nas Embaixadas Americanas espalhadas pelo mundo. Dentre suas limitadas funções em solo americano, variando de estado para estado estão: a) formalizar juramentos, afirmações e reconhecimentos, b) autenticar assinaturas, c) testemunhar e autenticar a execução de certos documentos como: procurações, declarações, atestados e outros, d) certificar depósitos, e) protesto de notas ou contas, f) testemunhar a abertura de cofres e descrevendo o conteúdo deste, g) realizar cerimônias do casamento civil. Alguns membros das forças armadas possuem a atribuição do Notary Public.

Nas embaixadas ${ }^{14}$ podem-se encontrar os seguintes serviços: a) traduções de documentos, b) cópias de documentos, c) inscription letter - documento para quem não possui o nome completo dos pais na certidão de nascimento, d) notary signature - o notário atesta que a parte assinou o documento em sua presença ${ }^{15}$, e) evidence as single marital status - declaração do estado civil de solteira.

\footnotetext{
14 EMBAIXADA AMERICANA NO BRASIL. Disponível em: <http://brazil.usembassy.gov/notaries.html>. Acesso em: 22 jan. 2015.

15 No Brasil é uma modalidade de reconhecimento de firma por autenticidade atesta que quem assinou o documento o fez na presença do titular da serventia e também assinou em livro próprio que fica arquivado neste. Para alguns atos da vida civil o reconhecimento de firma só é válido se feito nesta modalidade, como no exemplo do preenchimento do documento de compra e venda emitido pelo DETRAN.
} 
Hoje os EUA sofrem o grande problema da fraude dos notários. Pela facilidade de se inscrever como notário, muitos fraudadores fingem sê-lo e exercem a função e atestando os atos. A forma mais comum de encontrar esse tipo de fraude é com relação ao serviço de imigração. Muitos fraudadores oferecem seus serviços aos imigrantes, que de boa-fé tem seus documentos e assinaturas atestados por quem não possui atribuição para tanto.

Interessante perceber a diferença entre o sistema americano de notariado e o sistema brasileiro quando se faz a leitura da explicação What is a Notary Public? presente no site da Sociedade Americana dos Notários. Durante toda a explicação, há um enorme esforço em frisar sobre a importância da presença física da parte que deseja ter sua assinatura certificada pelo Notário e de como este deve interpretar a presença desta parte para atestar o livre arbítrio no ato. No Brasil pode-se atestar a assinatura em um documento mesmo que a parte não esteja presente, é a chamada autenticidade por semelhança.

No site da Associação Americana de Notários (American Society os Notaries) ${ }^{16}$, pode-se encontrar cursos online e ao vivo sobre a função no geral, bem como cursos específicos para cada estado. Há a possibilidade de se associar pelo site e receber as notícias de cursos e eventos, bem como comprar o material necessário para exercer a função que são as folhas timbradas, carimbos, certificados e livros.

\section{SISTEMA DE REGISTRO PÚBLICO BRASILEIRO - NOTÁRIO BRASILEIRO}

Derivado do Sistema de Notariado Latino debruçado no Civil Law cuja base de prova primordial são os documentos, o notariado brasileiro integra uma estrutura complexa, por muitos tida como burocrática e desnecessária, mas que auxilia a organização do Estado de forma eficiente e segura. O Sistema de Registro Público Brasileiro é dividido em Notas e Registro ${ }^{17}$. Iniciando com as características comuns para notas e registro, o texto é finalizado com as atribuições específicas de notas ${ }^{18}$.

Com relação a Notas, suas atribuições estão no serviço de notas em sentido estrito, contratos marítimos e protesto de títulos e outros documentos de dívida. Quanto aos dois últimos, além de exercerem a função Notas, eles exercem o registro de suas notas. Já o Registro é dividido em Registro de Imóveis (RGI), Registro de Títulos e Documentos e Civis das Pessoas Jurídicas (RTD), Registro de Pessoas Naturais e de Interdições e Tutelas (RCNP) e Registro de Distribuição (Distribuidor).

Tanto o notário/tabelião quanto o registrador são profissionais de direito ${ }^{19}$, com graduação em direito ou 10 anos de experiência na área comprovada via carteira de trabalho, habilitados por concurso público de provas e títulos, de no mínimo três fases (objetiva, discursiva e oral), podendo haver o exame psicotécnico. Além da habilitação devem possuir nacionalidade brasileira, capacidade civil, quitação com as obrigações eleitorais e militares, bem como a verificação de conduta condigna para o exercício da profissão.

${ }^{16}$ AMERICAN SOCIETY OF NOTARIES. Disponível em: <http:// http://www.asnnotary.org/>. Acesso em: 22 jan. 2015.

17 Art. $5^{\circ}$, Lei. 8.935/94 - Lei de Notários e Registradores (LNR)

18 Opto pelas características comuns exatamente porque a lei não as separa. Logo, se o leitor for se aprofundar no tema verá a similitude deste texto com a lei.

19 Art. 14 e 15, LNR. 
Depois de aprovados e investidos na função, eles passam a ser titulares das serventias que escolheram ${ }^{20}$ para exercer suas funções. Com a investidura, documento que prova a aprovação no concurso e escolha, o titular é investido de fé pública e seus atos são destinados a garantir a publicidade, autenticidade, segurança e eficácia ${ }^{21}$. Seus serviços que são de organização técnica e administrativa devem ser prestados em dia e horário estabelecidos pelo juiz competente da comarca em que sua serventia se localiza atentando as peculiaridades locais ${ }^{22},{ }^{23}$.

Esses titulares são agentes públicos na modalidade particulares em colaboração, não estando vinculados ou subordinados ao Estado nem sendo por este remunerado (diverso do que ocorre com o funcionário público). Adquirem, na investidura, o serviço público pela modalidade outorga ${ }^{24}$ de delegação. A titularidade do serviço continua com o estado, mas seu exercício é efetivado por um particular específico. A delegação do serviço é feita em caráter personalíssimo. Só o aprovado pode exercer a função. Caso ele faleça ou renuncie a delegação, sua serventia vaga e é aberto novo concurso para provêla.

A vinculação funcional do titular é administrativa com a Corregedoria Geral de Justiça do Estado em que prestou concurso, devendo obedecer às normas emanadas por esta corregedoria, podendo receber do Corregedor Geral ou do juiz com função correcional, penalidade administrativas, apesar de não serem vinculados aos quadros do Poder Judiciário.

Por se tratar de sistema de Civil Law, a função de notário e registrador se encontra presente em várias leis, iniciando pela lei maior, a Constituição Federal de 1988 que inovou quando trouxe a possibilidade do acesso as serventias através do concurso público específico para tal. Antes o acesso era por herança, nomeação de apadrinhados, por funcionários públicos de carreira do Tribunal de Justiça já no final de sua vida funcional, ou ainda através de concurso de acesso, para estes funcionários com prova específica para o cargo de escrivão, podendo ser alocados em cartório judiciais ou extrajudiciais (atuais serventias).

Os serviços de Notas e Registro estão inseridos na Constituição Federal, no capítulo das Disposições Constitucionais Gerais, em seu art. 236 e art. 32, ADCT, regulamentado pela Lei. 8.935/94. O dispositivo constitucional é de aplicabilidade imediata e eficácia plena. Apesar de o serviço ser público e entregue por delegação, ele é exercido em caráter privado, tendo, o poder público, poder de fiscalizar o serviço através das corregedorias vinculadas aos Tribunais de Justiça de cada estado. A competência para legislar sobre registros públicos é privativa da União (art. 22, XXV, CRFB/88).

A Constituição ainda indicou a necessidade de lei específica para disciplinar a responsabilidade civil e criminal dos Titulares e seus prepostos, que foi cumprida com a

\footnotetext{
20 Após a aprovação na prova oral é lançada a lista de aprovados de acordo com a classificação. Em data oportuna é marcada a seção de escolha onde os aprovados podem escolher entre as vagas indicadas no edital do concurso. A escolha é de qualquer vaga do edital. Não necessita do primeiro lugar escolher a primeira vaga. Ele pode escolher a última Serventia da lista, por exemplo.

${ }^{21}$ Art. $1^{\circ}$ e $2^{\circ}$, LNR.

22 Art. $3^{\circ}$, LNR.

${ }^{23}$ Como peculiaridade local se encontram as estações das chuvas, o ambiente rural, o calor exagerado do verão e outros.

24 Complexa essa natureza de Delegação, inclusive para os doutrinadores administrativistas que tentam conceituar a função. A investidura tem característica de Outorga e de Delegação, que administrativamente são coisas diversas. Enfim, investidura de Titular de Serventia não é nem outorga simples, nem delegação, é um elemento sui generis chamado de outorga da delegação.
} 
entrada em vigor da Lei 8.935/94, chamada lei dos Notários e Registrados (LNR). Esta lei regulamenta as atividades do art. 236, CRFB/88 trazendo normas de aplicação geral a todo serviço notarial e de registro, tais como: atribuições, norma de ingresso na atividade, responsabilidade, incompatibilidades e impedimentos, infrações e penalidades, fiscalização e extinção da delegação.

Além da Constituição Federal e da LNR, há a Lei de Registros Públicos (LRP) lei 6.015/73, que foi recepcionada e dispõe sobre normas gerais afetas a qualquer serviço notarial ou registral e específicas sobre RCPN, RCPJ, RTD e RGI. Com relação ao protesto de títulos, esta atribuição segue a lei 9.492/97, que trata especificamente do protesto e traz normas de caráter geral sobre responsabilidade do titular da serventia.

Regulamentando o $\S 2^{\circ}$ do art. 236, da Constituição existe a lei 10.169/00, dispondo sobre normas gerais para a fixação dos emolumentos, cabendo aos Estados organizarem seus serviços e sua tabela de emolumentos, sempre obedecendo às normas gerais. Nos Estados, normalmente, esta organização sobre os emolumentos está presente nas Consolidações Normativas Extrajudiciais ou em documento similar.

Fechando o rol de leis federais a serem seguidas pelas serventias de todo o Brasil se apresenta o Código Civil de 2002 que traz normas gerais como os requisitos da escritura pública (art. 215, CC/02) e normas específicas como o prazo da certidão de habilitação para casamento (art. 1.532, CC/02).

Aditivamente as leis, a regulação do serviço se dá, também, pelo Conselho Nacional de Justiça $(\mathrm{CNJ})^{25}$ que é responsável, junto com o Tribunal de Justiça de cada estado conhecer e receber reclamações contra os órgãos prestadores dos serviços notariais e de registro que atuem por delegação do poder público ${ }^{26}$ e editar resoluções sobre o serviço, como as Resoluções 80 e 81 de 2009, dispondo sobre a vacância dos serviços ocupados em desacordo com as normas constitucionais vigentes e sobre a unificação do concurso de ingresso da atividade com regras gerais em detrimento das estaduais vigentes.

E, por fim, a Consolidação Normativa Extrajudicial de cada Estado. Nela são encontradas normas gerais do serviço, sempre de acordo com a LRP, todavia abordando as peculiaridades de cada lugar. Como exemplos estão os tipos de livros, além dos mencionados na LRP, se esses livros serão físicos ou virtuais, os tipos de selos, forma de execução de cada serviço, documentos necessários para os serviços, indicação do que se arquiva na Serventia e por quanto tempo, indicação dos serviços permitidos e proibidos, indicação de dia e horário de funcionamento dentre outros. A Corregedoria, além de emitir a consolidação, pode ainda, indicar os feriados e outras datas que as serventias deverão ser fechadas.

A remuneração do serviço ${ }^{27}$ é paga pelos usuários através dos emolumentos. Deste valor recebido que é tarifado pela corregedoria de cada Estado, cerca de $20 \%$ do valor sobre cada serviço deve ser devolvido ao respectivo Tribunal de Justiça do Estado. Esta devolução se dá a título de pagamento pela delegação do serviço. Além do percentual do Tribunal, podem incidir outros percentuais para auxiliar a arrecadação de determinado ente, a exemplo o Arpen de São Paulo que é um fundo de apoio do titular de serventia deficitária ${ }^{28}$, o fundo da CAARJ, da Santa Casa dentre outros.

\footnotetext{
25 Discussões sobre o $\mathrm{CNJ}$ à parte pois não se trata do objeto deste artigo.

${ }^{26}$ Art. 103-B, $\S 4^{\circ}$, III, CF/88 e Art. $4^{\circ}$, XXV, Emenda Regimental 1/2010, CNJ.

${ }^{27}$ Art. 28, LNR.

${ }^{28} \mathrm{O}$ fundo de apoio das serventias deficitárias existe em vários Estados da federação. Nem todas as Serventias são rentáveis economicamente, mas todas devem ser mantidas abertas para prestar o serviço de notas e registro tão essencial aos atos da vida civil. Para essas Serventias que seu serviço não gera renda nem para pagamentos de suas
} 
O notário brasileiro é um híbrido das funções do Civil Law Notary com o Notary Public melhorado. Digo melhorado pelas características de seus serviços que transparecem maior segurança do ato. Dentre os serviços praticados pelo notário está a formalização jurídica da vontade das partes, a intervenção nos atos e negócios jurídicos a que as partes queiram ou devam dar forma legal ou autenticidade redigindo esses instrumentos, conservando os originais e expedindo cópias e certidões de seu conteúdo, além de autenticar os fatos.

Para tanto, os Notários possuem instrumentos específicos ${ }^{29}$, que nem o Registrador, nem o advogado, nem o juiz podem confeccionar. São eles: as escrituras e procurações públicas, as escrituras de testamentos públicos e aprovação dos testamentos cerrados, a Ata Notarial, a abertura e reconhecimento de firma que pode ser por semelhança ou autenticidade e a autenticação de cópias.

Os Cônsules, comandantes de tropa do exército em período de guerra, comandantes de navios e comandantes da aeronáutica tem a permissão para se utilizar de instrumentos próprios dos notários a exemplo das procurações, testamentos, ata notarial e autenticação de documentos; e próprios do registrador como o registro de nascimento, casamento e óbito. Esses atos serão efetivados no local onde se encontra a tropa, o navio ou aeronave, bem como no local da embaixada brasileira.

Os tabeliães de notas devem obedecer a circunscrição territorial ${ }^{30}$ para seus atos, ou seja, eles não podem sair de seu local de trabalho para fazer um ato notarial. Exceções: colheita de assinaturas de pessoas acamadas ou hospitalizadas - exemplo: Fulano sofreu um acidente e está acamado. Para facilitar resolver questões pendentes em banco, prefeituras, e outros, ele deseja fazer uma procuração outorgando poderes a sua esposa. Como não tem condições de ir à serventia, o titular desta pode vir até ele para colher sua assinatura do ato, sempre respeitando o território no qual recebeu sua delegação. Não pode buscar assinatura na Comarca vizinha.

Outra exceção pouco usada pelo seu desconhecimento, mas de grande valia, é a Ata Notarial. Através deste instrumento, o Titular comparece ao local e atesta o fato desejado pela parte que procurou o serviço. Exemplo: reunião de sociedade para atestar o decidido, cumprimento de acordo com retirada de bens móveis, certificação de pagamento, certificação de depósito, etc. E dentro da serventia, a Ata Notarial pode ser usada para certificar a existência de sites e de informações nos sites como calúnias e bullying nas redes sociais.

Apesar do notário não poder sair de sua serventia, salvo as exceções, as partes podem ir a qualquer serventia, de qualquer estado do Brasil para formalizar sua vontade. Às partes é livre a escolha do tabelião de notas qualquer que seja seu domicílio ou lugar de situação dos bens objeto do ato ou negócio ${ }^{31}$. O exemplo trazido na maioria dos livros de notarial é do casal que está aproveitando sua lua de mel viajando para outro estado e resolvem se divorciar. Sim, a escritura pública de divórcio pode ser feita em qualquer serventia de notas não importando o domicílio conjugal do casal.

O instrumento mais comum da serventia de notas é a escritura pública. Diferente do sistema norte-americano, na serventia só é emitido atos públicos na forma pública. E,

próprias despesas (há muitos casos!) o fundo de apoio envia uma quantia mensal ao Titular para auxiliar no pagamento de despesas básicas como água, luz, telefone, internet, papel, impressora, programa de computador para que este não devolva a Serventia ao Tribunal.

${ }^{29}$ Art. $6^{\circ}$ e $7^{\circ}$, LNR.

30 Art. $9^{\circ}$, LNR.

${ }^{31}$ Art. $8^{\circ}$, LNR. 
mesmo que o testamento seja cerrado (um dos tipos de testamentos particular) a aprovação deste e seu cerramento é ato público podendo dele ser emitido certidão que no dia $\mathrm{x}$ do mês $\mathrm{x}$ do ano x, Fulano esteve presente no Tabelionato de Notas x e pediu que aprovasse seu testamento cerrado.

Uma vez que a informação se formalizou num ato dentro da serventia está se torna pública. Excepcionando a regra, existem as informações que só são entregues a parte interessada e ao juiz da causa. Dentre elas está a filiação biológica da criança em caso de adoção, a mudança de nome por conta da mudança de sexo e do programa de proteção a testemunhas. Todas informações típicas do RCPN. E, com relação ao protesto, a certidão de protesto cancelado só pode ser emitida para o próprio devedor ou por ordem judicial. Os exemplos esclarecem o quanto a informação se torna pública.

Dos atos instrumentalizados nas serventias, qualquer interessado, quero dizer, qualquer pessoa, já que não precisa demonstrar o interesse direto na informação pode pedir uma certidão atestando uma existência de um instrumento na serventia. $\mathrm{O}$ titular não pode negar a informação ${ }^{32}$, mesmo sabendo que o requerente é o maior fofoqueiro da cidade. Essa publicidade traz segurança pois os interessados no negócio jurídico têm como extrair informação se quem está negociando possui poderes e capacidade para tanto. Walter Ceneviva ${ }^{33}$ explica:

a publicidade registrária se destina ao cumprimento de tríplice missão: a) transmite ao conhecimento de terceiros interessados ou não interessado a informação do direito correspondente ao conteúdo de registro excetuado apenas os sujeitos ao sigilo; b) sacrifica parcialmente a privacidade e a intimidade das pessoas, informando sobre bens e direitos seus que lhes sejam referentes, a benefício das garantias advindas do registro; c) serve para fins estatísticos, de interesse nacional ou de fiscalização pública.

A escritura pública é a forma pública onde pode ser moldada qualquer emissão pode vontade. Pode ser a vontade de vender uma posse, a vontade de emancipar um filho ou de reconhecer sua paternidade, pode ser a vontade de renunciar a herança, ou ainda que atestar uma dívida e informar que vai pagá-la mesmo já tendo transcorrido seu prazo prescricional. A declaração presente na Escritura Pública pode ser unilateral, como na doação, ou bilateral como na compra e venda e divórcio.

Contudo, para que esta seja efetivada, o titular deve atentar para alguns requisitos que são de sua responsabilidade. São eles a verificação da capacidade das partes podendo exigir a apresentação a certidão de interdição e tutela negativa, do objeto ser lícito, possível e determinável e da forma não ser proibida em lei. Além desses, o titular é responsável pela autoria do instrumento bem como pelo controle de legalidade adequando a vontade das partes à lei vigente.

A função notarial não se restringe a somente formalizar juridicamente vontade das partes. Seu cunho social é infimamente maior. O titular deve colaborar com a pacificação social prevenindo conflitos, resguardando o direito e desobstruindo o judiciário. Essa característica é uma marca do notariado latino que busca um profissional mais atento a sua função e com mais capacidade de mediar os conflitos.

${ }^{32}$ Art. 17, LRP

${ }^{33}$ CENEVIVA, Walter. Lei de Registros Públicos Comentada. 18. ed. rev. e atual. São Paulo: Saraiva, 2008, p. 37-38. 
Ele previne conflitos quando atende bem as partes que dirigem a sua serventia dando-lhes a melhor informação, de forma mais imparcial possível, auxiliando a resolverem seus problemas através dos instrumentos extrajudiciais de resolução de conflito. Muitas vezes uma retificação administrativa de área resolveria a briga entre os vizinhos.

Ele resguarda o direito quando emprega zelo em seu trabalho verificando os requisitos de cada ato e explicando e auxiliando as partes nos documentos necessários para sua realização; e, desobstruí o Judiciário quando trabalha com urbanidade recebendo as partes que desejam realizar escrituras de divórcio e inventário extrajudicial, bem quando tenta resolver seus conflitos através dos instrumentos presentes nas serventias.

No sistema brasileiro o notário não deve ser um indivíduo apático que só assina e carimba papéis. Esse sistema propõe que o Notário seja um auxílio na estrutura jurídica e, principalmente na brasileira pois o Estado delegou a este um serviço público de suma importância para os atos da vida civil em geral. A população confia no serviço. Nada mais justo que o notário haja com honestidade e empenho em seu trabalho.

\section{CONCLUSÃO}

Cada cultura traz seu traço marcante e a explicação do porquê de ser da forma que é. Não cabe ao homem impor seu direito, sua vontade. Ele deve entender o contexto social da cultura estudada a fim extrair desta, suas melhores qualidades, para depois indicar os erros e apresentar soluções. Em nosso mundo globalizado, impor é uma grande falta de inteligência. Com tanto a se aprender e a compartilhar buscando um modelo que chegue próximo ao ideal para a maioria, porque impor?

Quando se estuda a cultura norte-americana; seu esforço de separação da colônia que escravizava com altos impostos e sua tentativa de criar um novo mundo para os colonos ingleses insurgentes percebe-se a necessidade de a palavra ter valor. Um povo que possui sua cultura arraigada na honra da palavra, no mínimo acha estranho ter um terceiro, que provavelmente é um desconhecido, dizendo que a assinatura deste colono é dele mesmo. Como se ele não soubesse disso e como se sua palavra não valesse.

$\mathrm{Na}$ outra face da moeda, a cultura brasileira que teve seu território invadido por estrangeiros dizendo serem donos da terra, necessita ter um documento para protegê-lo contra novos invasores. Ele precisa de um terceiro, com prestígio e boa fama, que as sine um documento juntamente consigo, carimbe e sele para informar a todos que aquela terra ou aquele direito pertence a ele. A palavra pode ser atropelada pelo invasor; o documento, não. Mesmo rasgado ou queimado há a possibilidade da cópia do original que fica num arquivo público.

Enquanto o norte-americano precisava da palavra, o brasileiro precisava do documento e da publicidade. Para os colonos ingleses, aportar no novo continente significava a possibilidade de ter um pedaço de chão para iniciar uma vida livre das amarras inglesas. Era simplesmente cercar a terra e dizer para os vizinhos: - Este é o meu pedaço. Para os portugueses e os brasileiros nativos, ter seu pedaço de chão exigia procurar um capitão de capitania hereditária, externar sua vontade de possuir uma terra, confeccionar o documento, assinar, carimbar, selar e sim, ter sua terra. Assim, ela estava protegida contra invasores.

Os exemplos são simples e corriqueiros, mas elucidativos o bastante para entender a diferença do sistema notarial Norte-Americano para o Brasileiro. Por isso, nos EUA só 
há a necessidade do Notary Public já que os demais atos e contratos podem ser confeccionados pelas partes com auxílio de advogados e de agências do ramo. Enquanto a palavra possuir seu devido valor, o sistema funciona muito bem.

Diversamente ocorre no Brasil. Precisa-se de um sistema de registro público rígido, organizado, que se sustente, com ampla publicidade e acesso pela população. Deve, também, ser um serviço ágil, que permita o acesso à justiça por outro meio que não somente o judiciário tendo em vista a superlotação de serviço neste. $\mathrm{O}$ brasileiro tem a cultura de um terceiro, com autoridade, dizer o que se deve fazer, a quem pertence algo, ao simplesmente confirmar que a assinatura é da pessoa que o documento indica, ou ainda que a cópia confere com o original.

A fim de evitar as possíveis burlas trazendo melhor segurança aos usuários do serviço de registro, no Brasil, o sistema evoluiu chegando um serviço complexo, com uma organização ímpar como uma grande teia de informações que diminui os espaços da mentira através das palavras. Há a necessidade de prova documental a todo o tempo. Aos olhos dos norte-americanos e de grande parte dos brasileiros o registro público brasileiro é demasiadamente burocrático, desnecessário.

Contudo, quando a viúva brasileira não perde seu direito de pensão por possuir uma certidão de casamento em detrimento da companheira que nenhum documento comprovando a união estável possui, diz aos ventos que é o melhor sistema do mundo. $\mathrm{O}$ mesmo ocorre quando feito o inventário ou divórcio na serventia. A frase de satisfação geralmente é: - Bem mais rápido que na justiça. Olha só que rapidez. Morreu e dois meses depois já tem o inventário pronto.

Não há sistema de notariado certo ou errado. Há o mais adequado a cada cultura. Com a globalização as diferenças vão diminuindo expondo as semelhanças e as busca por novas soluções mais inovadoras ou até antigas, porém seguras e adaptáveis a nova ordem. O sistema pode ser do Common Law, mas nada impede que o tipo de Registro Público seja de Civil Law. Isto já vem ocorrendo em Quebec, Louisiana, Alabama e Flórida.

Com relação à importação, pelo direito, de institutos alienígenas, no Registro Público verifica-se um fenômeno inverso. O Brasil exporta este modelo. Vários países fazem visitas no Brasil para aprender como trabalhar com esse sistema registrário a fim de implantar em seu país. Tido como um modelo seguro e de sucesso traduzindo a transparência dos atos efetivados nas serventias, o Registro Público Brasileiro se tornou um modelo a seguir. Exportemos as jabuticabas!

\section{REFERÊNCIAS BIBLIOGRÁFICAS}

$2^{\circ}$ TABELIONATO DE PROTESTO DE PORTO ALEGRE - RS. Notariado Latino $x$ Anglo-saxão. Disponível em: <http://www.2tab.not.br/_img/files/artigo/ anglosaxao.pdf $>$ e $<$ http://www.2tab.not.br/home/index.php?submenu=artigos $>$. Acesso em: 22 jan. 2015.

AMERICAN SOCIETY OF NOTARIES. Disponível em: <http:// http://www.asnnotary.org/>. Acesso em: 22 jan. 2015.

ASN. How to Become a Notary - Frequently Asked Questions. American Society of Notaries. Disponível em: 〈http://www.asnnotary.org/?form=faqs>. Acesso em: 22 jan. 2015. 
AVM Instituto. História do Direito Notarial e Registral. Disponível em: http://lms.ead1.com.br/webfolio/Mod1270/mod_historia_do_direito_notarial_v2.pdf. Acesso em: 22 jan. 2015.

BRASIL. Conselho Nacional de Justiça. Emenda Regimental n ${ }^{\circ}$ 1, de 09/03/2010. Publicado no DJ-e, $\mathrm{n}^{\circ}$ 60/2010, de 5 de abril de 2010, p. 2-6. Disponível em: <http://www.cnj.jus.br/regimento-interno-e-regulamentos>. Acesso em: 22 jan. 2015.

BRASIL. Constituição Federal de 05/10/1988. Disponível em: <http://www.planalto.gov.br/ccivil_03/constituicao/constituicaocompilado.htm>.

Acesso em: 22 jan. 2015.

BRASIL. Lei 10.406 de 10/01/2002. Disponível em: <http://www.planalto.gov.br/ ccivil_03/leis/18935.htm>. Acesso em: 22 jan. 2015.

BRASIL. Lei 6.015 de 31/12/1973. Disponível em: <http://www.planalto.gov.br/ ccivil_03/leis/L6015original.htm>. Acesso em: 22 jan. 2015.

BRASIL. Lei 8.935 de 18/11/1994. Disponível em: <http://www.planalto.gov.br/ ccivil_03/leis/18935.htm>. Acesso em: 22 jan. 2015.

CENEVIVA, Walter. Lei de Registros Públicos Comentada. 18. ed. rev. e atual. São Paulo: Saraiva, 2008.

Lei de Notários e Registradores Comentada. 5. ed. rev. e atual. São Paulo:

Saraiva, 2006.

COLÉGIO NOTARIAL DO BRASIL - CONSELHO FEDERAL. Disponível em: <http://www.notariado.org.br>. Acesso em: 22 jan. 2015.

DINIZ, Maria Helena. Sistemas de Registro de Imóveis. 9. ed. rev. e atual. São Paulo: Saraiva, 2010.

EMBAIXADA AMERICANA NO BRASIL. Disponível em: <http://brazil.usembassy.gov/notaries.html>. Acesso em: 22 jan. 2015.

FORMICOLLA,Tullio. O Notariado no Brasil e no Mundo. Colégio Notarial do BrasilDF. Disponível em: <http://www.notariado.org.br/index.php?pG= X19leGliZV9ub3RpY2lhcw==\&in=MzQ1Mw==\&filtro=9\&Data=>. Acesso em: 22 jan. 2015.

JACOMINIO, Sérgio. Audes notariais (nos EEUU). Observatório do Registro. Disponível em: <http://cartorios.org/2009/12/27/fraudes-notariais-nos-eeuu/ > Acesso em: 22 jan. 2015.

JACOMINO, Sérgio. Tio Sam e a Fé Pública. Observatório do Registro. Disponível em: <http://cartorios.org/2008/12/05/tio-sam-e-a-fe-publica/> Acesso em: 22 jan. 2015.

KARAMBELAS, Nicholas G. Civil Law Notary: An Office Whose Time Has Come? Washington Lawyer, March 2005. Disponível em: <http://www.dcbar.org/barresources/publications/washington-lawyer/articles/march-2005-notary.cfm>. Acesso em: 22 jan. 2015.

LINS, Caio Mário de Alburqueque. A atividade Notarial e de Registro. Coleção Concurso para Notários e Registradores. Companhia Mundial de Publicações, 2010.

MACHADO, Ana Amélia Marquezi; AMARAL, Sérgio Tibiriçá. A Evolução Histórica do Direito Notarial. Faculdades Integradas Antônio Eufrásio de Toledo. Disponível em: <http://intertemas.unitoledo.br/revista/index.php/ETIC/article/viewFile/ 1619/1543>. Acesso em: 22 jan. 2015.

COLÓN, Dennis Martínez. O continente americano e a variedade de seus notariados. Entrevista concedida ao Colégio Notarial do Brasil - DF, Disponível em: <http://www.notariado.org.br/index.php?pG=X19leGliZV9ub3RpY2lhcw==\&in=NTA $4 \mathrm{Mg}==>$. Acesso em: 22 jan. 2015. 
MIRANDA, A. P. M. . Cartórios: onde a tradição tem registro público. Antropolítica (UFF), Niterói, v. 8, p. 59-75, 2000.

NASCIMENTO, Lafaiete Luiz do. Yes, We Can Register! Colégio Notarial do Brasil. Disponível em: <http://www.notariado.org.br/blog/?link=visualizaArtigo\&cod=304> Acesso em: 22 jan. 2015.

OLIVEIRA, Marcelo Salaroli de. Publicidade Registral Imobiliária. São Paulo: Saraiva, 2010.

PARISIUS LL.M., Henry. The difference between a Civil Law Notary and a Notary Public. Notary Office SPS. Disponível em: <http://notarysps.com/civlawnot.htm>. Acesso em: 22 jan. 2015.

RODRIGUES, Marcelo Guimarães. A crise das hipotecas podres e o registro de imóveis. Migalhas. Disponível em: <http://www.migalhas.com.br/dePeso/ 16,MI143120,101048A+crise+das+hipotecas+podres+e+o+registro+de+imoveis>. Acesso em: 22 jan. 2015.

VRIES LLM, Lars de. CONVEYANCE OF REAL ESTATE, The Role of a Civil Law Notary. Notary Office SPS. Disponível em: <http://notarysps.com/conveyance.htm>. Acesso em: 22 jan. 2015.

Recebido em: 15 de abril de 2016.

Aprovado em: 08 de maio de 2016. 